\title{
Detection of HCV-RNA in saliva of patients with chronic hepatitis $\mathrm{C}$
}

\author{
P Couzigou, L Richard, F Dumas, L Schouler, H Fleury
}

\begin{abstract}
Previous studies have provided conflicting results on the presence of hepatitis C virus-RNA in saliva. In this study, 23 $(62 \%)$ of 37 patients tested positive for hepatitis $C$ virus-RNA in saliva, using polymerase chain reaction analysis. A slightly greater proportion had a sporadic rather than a parenteral origin of chronic hepatitis C. These results provide a biological basis for saliva as a possible source of hepatitis $C$ virus (HCV) infection, but do not necessarily imply transmission by this route.

(Gut 1993; supplement: S59-S60)
\end{abstract}

We carried out a study using the polymerase chain reaction (PCR) test to determine whether HCV-RNA is present in the saliva of patients with chronic HCV infection.

\section{Patients}

Thirty seven patients (mean age 49 years, range 26-72) with chronic HCV proved histologically were included in the study. Twenty three had known parenteral exposure to HCV, while 14 had HCV of unknown origin (sporadic). All were positive for antibodies to $\mathrm{HCV}$
Hepatogastroenterology Department, Centre Hospitalier

Universitaire de

Bordeaux,

Pessac, France

$P$ Couzigou

F Dumas

L Schouler

Virology Laboratory,

Bordeaux II

University,

Bordeaux, France

L Richard

H Fleury

Correspondence to:

Dr P Couzigou,

Hepatogastroenterology

Department

Centre Hospitalier

Universitaire de Bordeaux,

Hôpital Haut Levêque,

Pessac 33604, France.

(anti-HCV) on second generation ELISA and there was no other cause of liver disease.

\section{Methods}

SALIVA COLLECTION

Saliva was collected before antiviral treatment and stored immediately at $-20^{\circ} \mathrm{C}$. In samples testing positive on PCR, absence of blood in

TABLE I HCV-RNA in saliva

\begin{tabular}{llll}
\hline & $\begin{array}{l}\text { Parenteral } \\
\text { exposure } \\
n(\%)\end{array}$ & $\begin{array}{l}\text { Unknown } \\
\text { transmission } \\
n(\%)\end{array}$ & $\begin{array}{l}\text { Total } \\
n(\%)\end{array}$ \\
\hline HCV-RNA positive & $12(52)$ & $11(78)$ & $23(62)$ \\
HCV-RNA negative & $11(48)$ & $3(22)$ & $14(38)$ \\
Total & 23 & 14 & 37 \\
\hline
\end{tabular}

TABLE II Published data on HCV-RNA in saliva

\begin{tabular}{|c|c|c|c|c|c|c|}
\hline & \multirow[t]{2}{*}{$\begin{array}{l}\text { Takamatsu } \\
1990^{\prime}\end{array}$} & \multirow[t]{2}{*}{$\begin{array}{l}\text { Wang } \\
1991^{2}\end{array}$} & \multicolumn{2}{|c|}{$\begin{array}{l}\text { Komiyama } \\
1991^{3}\end{array}$} & \multirow[t]{2}{*}{$\begin{array}{l}\text { Hsu } \\
1991^{4}\end{array}$} & \multirow[t]{2}{*}{$\begin{array}{l}\text { Fried } \\
1992^{5}\end{array}$} \\
\hline & & & Treated & Untreated & & \\
\hline $\begin{array}{l}\text { HCV-RNA positive } \\
\text { HCV-RNA negative } \\
\text { Total }\end{array}$ & $\begin{array}{l}5 \\
0 \\
5\end{array}$ & $\begin{array}{l}3 \\
0 \\
3\end{array}$ & $\begin{array}{l}0 \\
7 \\
7\end{array}$ & $\begin{array}{l}2 \\
4 \\
6\end{array}$ & $\begin{array}{r}0 \\
16 \\
16\end{array}$ & $\begin{array}{r}0 \\
14 \\
14\end{array}$ \\
\hline
\end{tabular}

saliva was controlled by Labstix test strip (Ames, Miles Company, Puteaux, France).

\section{RNA PREPARATION}

HCV-RNA was extracted from $200 \mu$ of saliva using guanidinium isothiocyanate and phenolchloroform isoamylalcohol, precipitation by isopropanol, and purification with $70 \%$ ethanol.

RETROTRANSCRIPTION

Retrotranscription was carried out using 200 IU of Moloney murine leukaemia virus reverse transcriptase and $10 \mu \mathrm{RNA}$.

\section{NESTED PRIMER TECHNIQUE}

Two rounds of PCR were performed to amplify the highly-conserved 5' nontranslated region of the HCV genome: outer primers: 5' TGC GGG CGA CAC TCC ACC ATA GAT 3' (sense) and 5' CGT GCT GGT GCA CGG TGT ACG AGA CCT 3' (antisense); inner primers: 5' CCA CCA TAG ATC ACT CCC CTG T 3' (sense) and 5' CAC TCG CAA GCA CCC TAT CAG GCA GT 3' (antisense).

The presence of a $286 \mathrm{bp}$ band in the second amplification was considered a positive result. Negative and positive controls were included during the extraction and PCR processes. Statistical analysis was carried out using nonparametric tests.

\section{Results}

Of the 37 patients tested, $23(62 \%)$ were found to be positive for HCV-RNA in saliva (Table I). A slightly, but not significantly, higher proportion of patients with sporadic infection tested positive compared with those with known parenteral exposure.

\section{Discussion}

Previous studies have provided conflicting results on the presence of HCV-RNA in saliva (Table II). The difference between the studies may be because of differing time intervals between collection and storage and different methodology, or both, especially in the separation/non-separation of cells in the saliva. In our laboratory, preliminary data indicate a reverse from positive to negative results when samples are frozen after three hours at room temperature rather than immediate freezing. In 
contrast with the studies of Fried $^{5}$ and, possibly, $\mathrm{Hsu}^{4}{ }^{4}$ in our study cells are not removed before extraction of RNA. Presence of HCV-RNA in cells, especially mononuclear cells, has recently been described by Artini ${ }^{6}$ and Romeo. ${ }^{7}$

\section{Conclusions}

The presence of HCV-RNA in saliva provides a biological basis for saliva as a possible source of $\mathrm{HCV}$ infection, although it does not necessarily imply transmission. To date, no undisputed case of $\mathrm{HCV}$ saliva transmission has been documented.

This work was supported in part by a Schering-Plough grant.
1 Takamatsu K, Koyanagi Y, Okita K, Yamamoto N. Hepatitis C virus RNA in saliva. Lancet 1990; 336: 1515.

2 Wang J-T, Wang T-H, Lin J-T, et al. Hepatitis C virus RNA in saliva of patients with post-transfusion hepatitis C infection (letter). Lancet 1991; 337: 48.

3 Komiyama K, Moro I, Mastuda Y, et al. HCV in saliva of chronic hepatitis patients having dental treatment (letter). chronic hepatitis patients having dental treatment (letter). Lancet 1991; 338: 572-3.

$4 \mathrm{Hsu} \mathrm{HH}$, Wright TL, Luba D, et al. Failure to detect hepatitis $\mathrm{C}$ virus genome in human secretions with the polymerase chain reaction. Hepatology 1991; 14: 763-7.

5 Fried MW, Shindo M, Fong TL, Fox PC, Hoofnagle JH, Di Bisceglie AM. Absence of hepatitis C viral RNA from saliva and semen of patients with chronic hepatitis C. Gastroenterology 1992; 102: 1306-8.

6 Artini M, Natoli G, Avantaggiati ML, et al. Replication of hepatitis $\mathrm{C}$ virus in the peripheral blood mononuclear cells from chronically infected patients. 7 Hepatol 1992; 16 (suppl 1): S3.

7 Romeo R, Theirs V, Driss F, Berthelot P, Nalpas B, Brechot C. HCV RNA in plasma and peripheral mononuclear blood cells of anti-HCV positive blood donors with or without increased ALT levels. F Hepatol 1992; 16 (suppl 1): S57. 